\title{
Modern aspects of the application of information and communication technologies in the management of the statistical industry of the Republic of Uzbekistan
}

\author{
Zhukovskaya Irina Evgenievna ${ }^{1}$ \\ ${ }^{l}$ Head of the Department of Information Technologies in Economics, \\ Tashkent State University of Economics Associate Professor, Republic of Uzbekistan
}

Email: irina.j@umail.uz.

\begin{abstract}
This article discusses the modern aspects of the application of information and communication technologies (ICT) in the management of the statistical industry of the Republic of Uzbekistan. The article shows that at present, ICTs are an important factor in the development of industries and spheres of the national economy. An information system has been formed in the statistical industry, which is currently being transformed under the influence of advanced technological solutions, including big data technology, which contributes to the competent adoption of managerial decisions and the effective functioning of the industry in the economic market.

Keywords: information and communication technologies, efficiency, competitiveness, innovative processes, quality of information processing and transmission, reliability and transparency of information, remote information processing, digital economy.
\end{abstract}

\section{INTRODUCTION}

The development and widespread use of information and communication technologies (ICT) in all sectors of the economy and spheres of human life is today a global trend in world development.

The use of modern ICTs helps to increase the competitiveness of countries in the global economic market, improve the living standards of citizens, optimize management processes and develop the social sphere of society. From year to year, ICTs open up wider prospects for improving business efficiency and the quality of life of citizens.

Currently, intensive work is underway in the Republic of Uzbekistan on the development of the ICT sector. A solid regulatory framework for the ICT industry has been created, almost all government facilities have representative offices on the Internet. A whole range of national projects is being implemented, such as Digital Uzbekistan-2030, E-Government, Safe City, etc.

Issues of the effective use of ICT in economic processes are studied by scientists from different countries in various aspects: theoretical, technical, technological, both quantitative indicators and qualitative characteristics of the effective use of ICT are considered [1]. Data from international experts indicate that the larger the share of ICT in the country's gross domestic product, the more competitive the country is in the global economic market. Thus, the share of ICT in the gross domestic product of South Korea is 9\%, in Japan $-5.5 \%$, in China and India - 4.7\%, and in Uzbekistan this figure is only $2.2 \%$ so far [9].

The importance of developing this sector of the national economy is evidenced by the fact that, as part of the implementation of the national program "Years of Active Investment and Social Development", a new joint venture LLC INFORMATION TECHNOLOGY CENTER, founded by Delta Telecom International I, LLC (USA), was created ) (51\% of the charter capital) and the State Unitary Enterprise Republican Telecommunication Networks Management Center of Uzbekistan under the Ministry of Development of Information Technologies and Communications of the Republic of Uzbekistan $n$ (49\% of the share capital).

Modern ICTs are an important factor in the development of sectors and spheres of the national economy of Uzbekistan. 


\section{LITERATURE REVIEW}

A great contribution to the development of the theory of the effective use of ICT in management processes was made by such foreign scientists as N. Vinner, K.S. Laudon [2], O. Mahlup, J. F. Neumann, M. Hammer, C. Shannon, W. Ashby, and others.

Modern management processes involve the use of big data technology, it should be noted that a whole list of works by foreign researchers is also devoted to this subject. A study by N. Couldry and A. Powell [3] is devoted to the analysis of the concepts of "large databases", as well as to the history of the emergence of large databases, and B. Hesse, R. Moser, and W. Riley study the process of implementing big data in the development of social processes .

A significant part of scientists considers the possibilities, limitations and threats associated with the implementation of big data analysis in public administration practice [4]. However, many note that further understanding of the possibilities of using big data in public administration is necessary, and it is possible to use the experience of large corporations that have been using big data for a long time to analyze markets, consumer behavior and other processes.

J. Frith emphasizes that when using big data, it is important to remember their interpretation and communication for more optimal processing of information [5].

Russian scientists also repeatedly in their scientific works turn to the study of the effective use of modern ICT in the management processes of various economic objects of the economy. These include such scientists as V.M. Glushkov, A.M. Venderov, S.P. Kutsenko, G.A. Titorenko [6], A.N. Romanov, V.E. Kosarev [7] and others, in whose writings the methodological approaches to the development of ICT in various sectors and spheres of the economy are described. Proceedings of V.V. Dick reflect the methodology for the formation of optimal solutions in economic systems, as well as the tools necessary for their analysis and support.

A whole complex of scientific studies of domestic scientists is devoted to solving issues on the effective use of ICT in the sectors and spheres of the national economy of the Republic of Uzbekistan in the context of the digital economy. This is the work of V.K. Kabulova, S.S. Gulyamova, R.Kh. Alimova, B.Yu. Khodieva, B.A. Begalova, A.N. Aripova, A.S. Abdugaffarova, A.T. Kenzhabaeva, S.S. Kasymova, T.F. Bekmuradova, R.A. Dadabaeva, B.K. Gayibnazarova, T.Sh. Shodieva, D.M. Rasuleva, A.T. Shermukhamedova, A.A. Musalieva B.T. Salimova et al.

Despite a significant number of publications, the problem of the effective use of ICT in the management processes of the statistical industry of the Republic of Uzbekistan is relevant.

\section{ANALYSIS AND RESULTS}

According to the State Committee of the Republic of Uzbekistan on Statistics, the volume of communication and information services for the period from January to June 2019 amounted to 4758.3 billion soums. Their growth compared to the same period last year amounted to $8.2 \%$. In the total volume of market services provided, the share of informatization communication services amounted to $5.7 \%$ [9].

It should also be noted that currently the most widely used mobile devices. This trend is due to lower prices for smartphones and ease of use of mobile devices in everyday life, an increase in the number of users of mobile Internet.

As can be seen from fig. 1. Today, among the operating systems of Uznet, almost $60 \%$ are mobile, $36 \%$ are on the Windows operating system, and only $6 \%$ are on other operating systems.

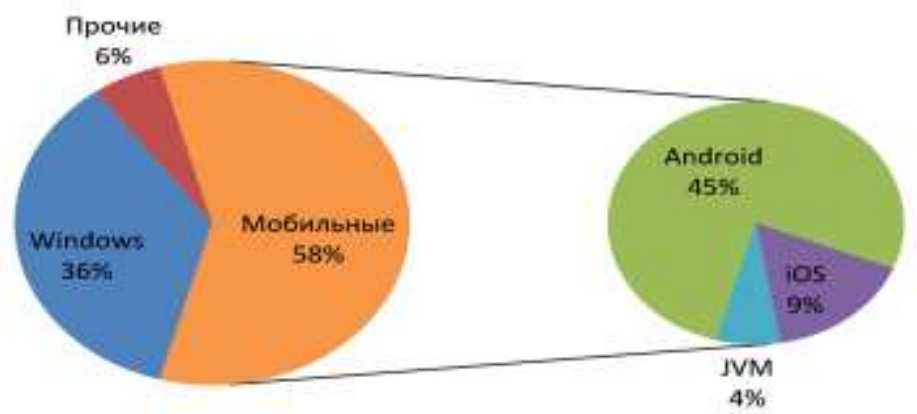

Fig. 1. The current ratio of Uznet's operating systems (in\%) [9] 
In fig. 2. The forecast values of the number of Internet users in Uzbekistan are presented, as well as the increase in throughput of an external access channel to international computer networks.

Another area of development of modern ICTs is the Internet of Things (IoT). One of the first applications in Uzbekistan could be the public services sector, where the installation of electronic meters for metering electricity, water and gas can implement the functions of automatic control of the supply of energy, water and gas supply services. Another direction is all kinds of smart systems and so on [9].

In addition, it should be noted that modern ICTs have great potential for stimulating social development. In particular, more and more modern ICTs are used in medicine, education, and the provision of a huge range of public services.

Thus, modern ICTs help to accelerate scientific and technological progress in the sectors and sectors of the national economy by increasing the volume, quality and speed of processing information flows, converting information into a form convenient for making effective management decisions based on high-quality and reliable data [8].

Figure 3 shows the structure of communication and information services in the Republic of Uzbekistan for January - June 2019.

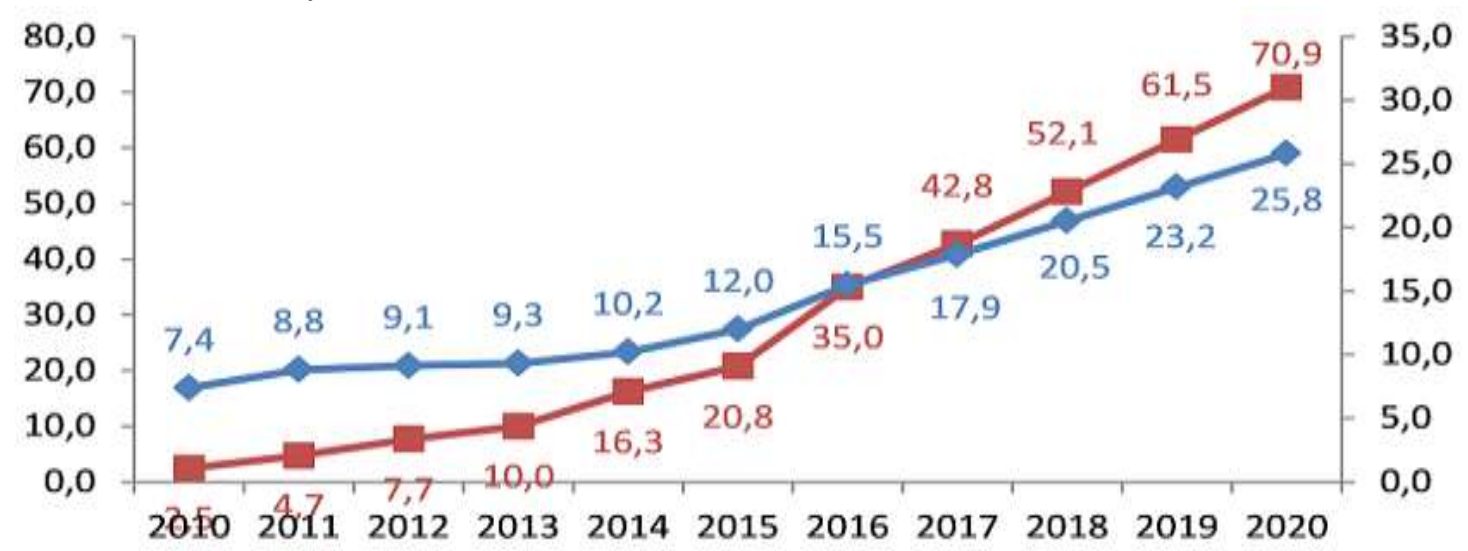

Fig. 2. Forecast of the number of Internet users in Uzbekistan and the throughput of an external access channel to international networks [9]

As can be seen from this figure, telecommunications services (82.1\%) have the largest percentage, almost the same percentage is in computer programming services (5.6\%) and publishing services (5.5\%), and various communication and information services account for 3.6\%, programming and broadcasting services are represented in this structure $3.2 \%$ [10].

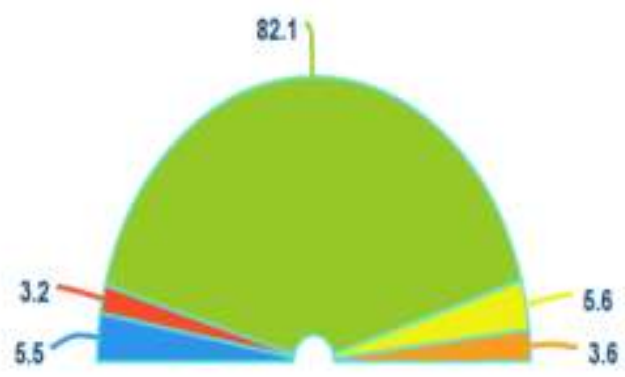

Fig. 3. The structure of communication services and informatization in January - June $2019, \%[10]$

Figure 4 shows the percentage of telecommunication services in the total volume of communication and information services in the regions of Uzbekistan for the first half of 2019, in percent.

As can be seen from fig. 4, high growth rates were noted in Jizzakh (99.2\%), Syrdarya (98.2\%), Samarkand (97.8\%), Kashkadarya (97.0), Andijan (96.8), Navoi (96.7 \%), Khorezm (96.6\%), Namangan (96.4\%), etc. The increase in volume can be explained by the influence of a number of factors, such as payment for goods through credit cards, Internet sales, the opening of new shopping centers, optimizing 
the functioning of the hotel sector, catering, the expansion of services of educational organizations and the entertainment industry.

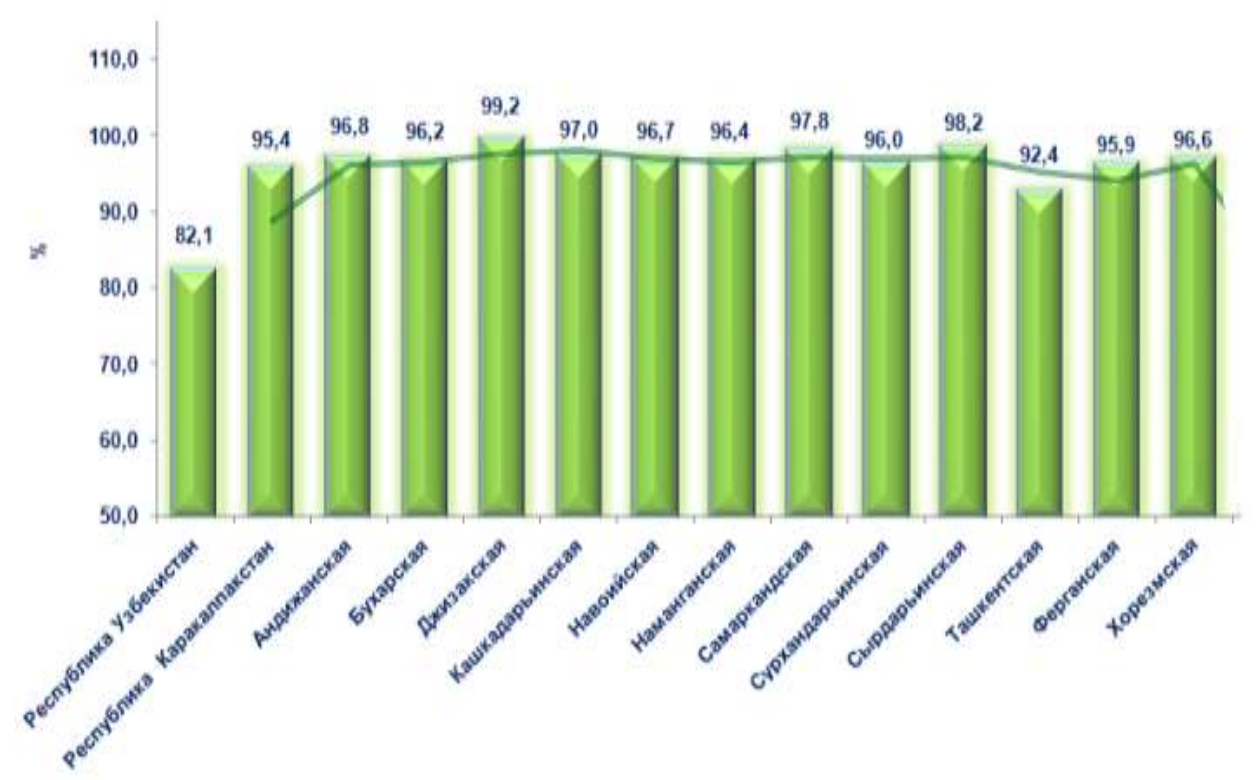

Fig. 4. Share of telecommunication services in the total volume of informatization communication services by region of the Republic of Uzbekistan for January-June 2019, in\% [10]

The lowest growth rates were recorded in the Tashkent region (92.4\%) due to the fact that the information and communication infrastructure in this area is by far the most developed. On average, in Uzbekistan, the share of telecommunication services in the total volume of communication and information services amounted to $82.1 \%$. In turn, in the structure of existing enterprises and service sector organizations as of July 1, 2019, enterprises and organizations providing communication and information services make up $3.1 \%$. [ten].

Management of the statistical sector of the national economy is a dynamic phenomenon in the context of the digital economy, its existence is impossible without the use of innovative technological solutions and ICT tools.

A public administration body implementing a unified policy aimed at the creation and functioning of a coherent progressive statistical information system based on scientific methodology, international standards and rules, taking into account national specifics of development, satisfying the needs of public authorities and management, business entities, citizens and organizations in an official statistical information in the field of statistics in the Republic of Uzbekistan, is the State Committee ie the Republic of Uzbekistan on Statistics [10].

The State Committee of the Republic of Uzbekistan on Statistics provides the organization of statistical work on the basis of the following principles:

- reliability, objectivity, impartiality;

- relevance, comparability and stability;

- accessibility, transparency and openness;

- exclusion of any interference with the procedure for collecting, processing and summarizing statistical information [10].

Management of the statistical industry on the basis of compliance with these principles is unthinkable without the effective use of modern information and communication technologies.

The modern information system of the State Committee of the Republic of Uzbekistan on Statistics includes a whole range of subsystems: specialized specialists, hardware, software that implements data processing using various management methods and models based on special algorithms (Fig. 3.). 


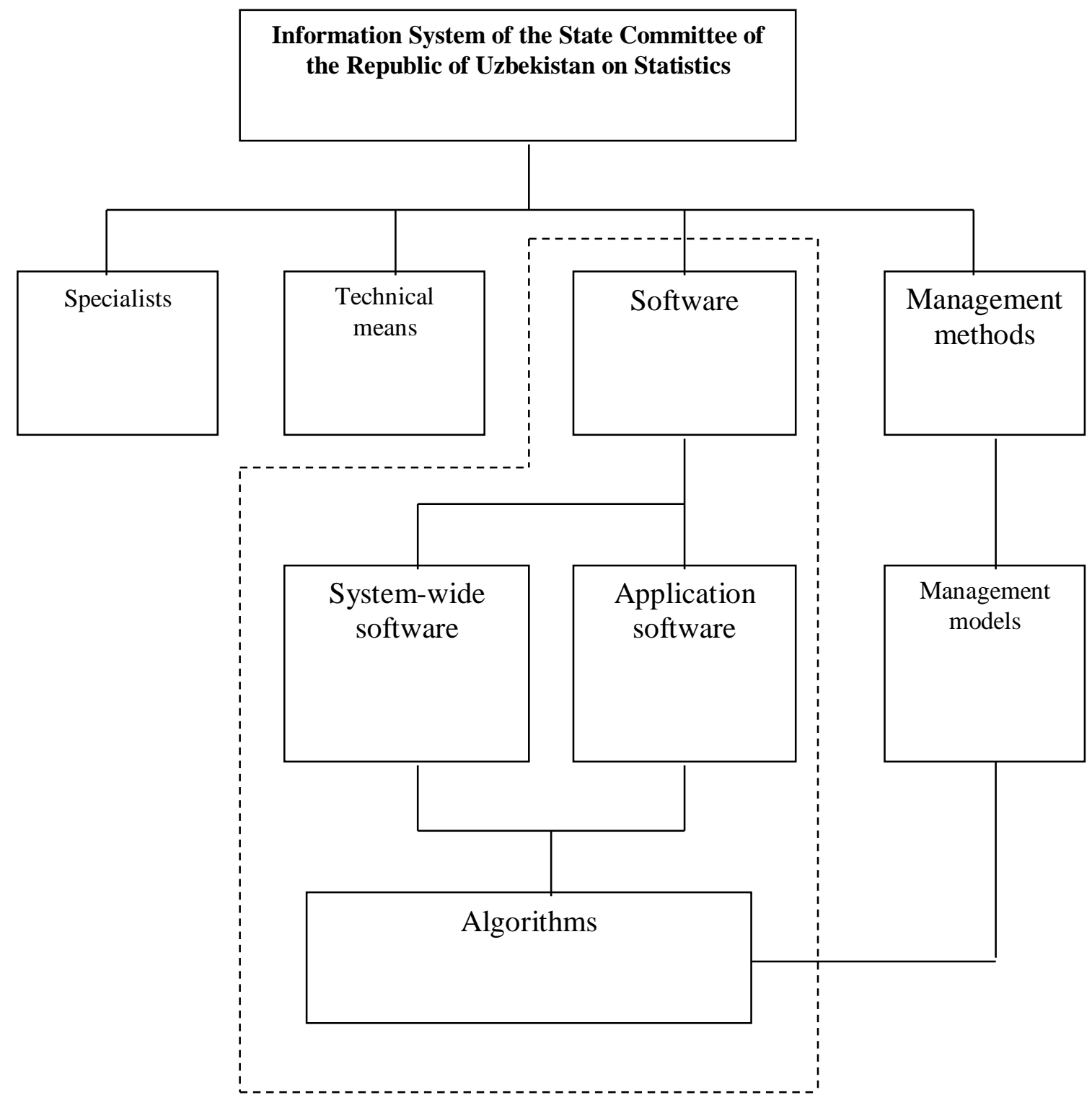

Fig. 5. The generalized scheme of the information system of the State Committee of the Republic of Uzbekistan on statistics

As can be seen from fig. 5. The main components of the information system of the Goskomstat of the Republic of Uzbekistan are specialized specialists in the management apparatus, complexes of hardware and software, models and methods for processing statistical information, and teaching materials. The main goal of the information system of the State Statistics Committee of the Republic of Uzbekistan is the complete and timely satisfaction of the information needs of end users.

Currently, the State Committee of the Republic of Uzbekistan on Statistics has a whole range of information systems (Table 1.). All systems, except the information system "Human Resource Management" and the electronic document management system of Goskomstat, are provided for access via the global computer network Internet [10].

Table 1.

Information on information systems functioning in the structure of the State Committee of the Republic of Uzbekistan on statistics

\begin{tabular}{|c|c|c|c|}
\hline № & Information System Name & The main tasks performed by the information system \\
\hline $\mathbf{1}$ & $\mathbf{2}$ & \multicolumn{3}{|c|}{$\mathbf{3}$} \\
\hline \multirow{2}{*}{ 1. } & $\begin{array}{l}\text { Human Resources Information } \\
\text { System }\end{array}$ & $\begin{array}{l}\text { 1. } \\
\text { 2. Staff management; } \\
\text { Reception, relocation, transfer between } \\
\text { departments; }\end{array}$ \\
\hline
\end{tabular}




\begin{tabular}{|c|c|c|}
\hline № & Information System Name & The main tasks performed by the information system \\
\hline 1 & 2 & 3 \\
\hline & & $\begin{array}{l}\text { 3. Training, retraining and certification of } \\
\text { employees; } \\
\text { 4. Dismissal of employees; } \\
\text { 5. Support for various compensation schemes; } \\
\text { 6. Payroll }\end{array}$ \\
\hline 2. & $\begin{array}{l}\text { Electronic library of teaching } \\
\text { materials "E-stat Library" }\end{array}$ & $\begin{array}{l}\text { Providing methodological provisions and instructions } \\
\text { for organizing and conducting statistical observations }\end{array}$ \\
\hline 3. & $\begin{array}{l}\text { Information and analytical system } \\
\text { "Gender statistics of Uzbekistan" }\end{array}$ & $\begin{array}{l}\text { The website gender.stat.uz in three language versions } \\
\text { - Uzbek, Russian and English - provides users with } \\
\text { information on the gender aspect in such areas as } \\
\text { demography, healthcare, education, labor, social protection } \\
\text { and others. } \\
\text { All statistical information on this site is presented in the } \\
\text { form of tables and animation diagrams. }\end{array}$ \\
\hline 4. & $\begin{array}{l}\text { Automated information system for } \\
\text { collecting statistical reports in } \\
\text { electronic form "eStat 3.0" }\end{array}$ & $\begin{array}{l}\text { Automation of the process of collecting statistical } \\
\text { information from legal entities in the prescribed manner }\end{array}$ \\
\hline 5. & $\begin{array}{l}\text { Automated information system for } \\
\text { accounting and identification of } \\
\text { legal entities based on the USRPO } \\
\text { "Reg-System" }\end{array}$ & $\begin{array}{l}\text { The tasks of the information system are the automation } \\
\text { of the processes of accumulation, storage, control and analysis } \\
\text { of information on legal entities received from registering and } \\
\text { other state bodies, as well as the provision of information in } \\
\text { the prescribed manner to government bodies and other users }\end{array}$ \\
\hline 6. & $\begin{array}{l}\text { Base database of electronic } \\
\text { statistical reports "Base" }\end{array}$ & $\begin{array}{l}\text { Storage of information on statistical reports of economic } \\
\text { entities entering the State Committee of the Republic of } \\
\text { Uzbekistan according to the statistics }\end{array}$ \\
\hline 7. & $\begin{array}{l}\text { Goskomstat electronic document } \\
\text { management system }\end{array}$ & $\begin{array}{l}\text { Improving paperwork, automation of information } \\
\text { support for decision-making processes, creating a unified } \\
\text { system of document accounting, systematization and control } \\
\text { of their implementation }\end{array}$ \\
\hline 8. & $\begin{array}{l}\text { Web Services: } \\
\text { - Consumer price index calculator; } \\
\text { - on-line counter of the population } \\
\text { of Uzbekistan }\end{array}$ & Work in relevant areas using web-technologies \\
\hline
\end{tabular}

Thus, it should be noted that at present, the information system of the State Committee of the Republic of Uzbekistan on statistics has been formed, which is a combination of information resources, information systems, software and hardware and telecommunications facilities of state statistics bodies, providing for the collection, processing, storage and use of statistical information .

ICTs help to accelerate scientific and technological progress in the sectors and sectors of the national economy by increasing the volume, quality and speed of processing information flows, converting information into a form convenient for making effective management decisions based on high-quality and reliable data.

In addition, it should be noted that ICTs provide new methods, forms and tools for developing scientifically sound and maximally competent management decisions.

Modern experts consider not only the positive, but also the negative aspects of the impact of ICT on economic and social processes.

So, the following are called as negative consequences of the introduction of ICT:

$>$ reduction of personal space and information inequality;

> loss of user anonymity when using computer networks;

$>$ The problem of computer ethics and the growth of computer crimes;

$>$ unification of cultures. 
But, despite the presence of shortcomings, ICTs in the era of the formation of the digital economy have many positive aspects:

$>$ free access to various sources of information;

$>$ distance and continuity of education;

$>$ improving the quality of life of people with disabilities;

$>$ Creation of own information arrays and their transfer to any user.

In fig. 6 shows the main directions of the impact of ICT on the statistical industry of the Republic of Uzbekistan.

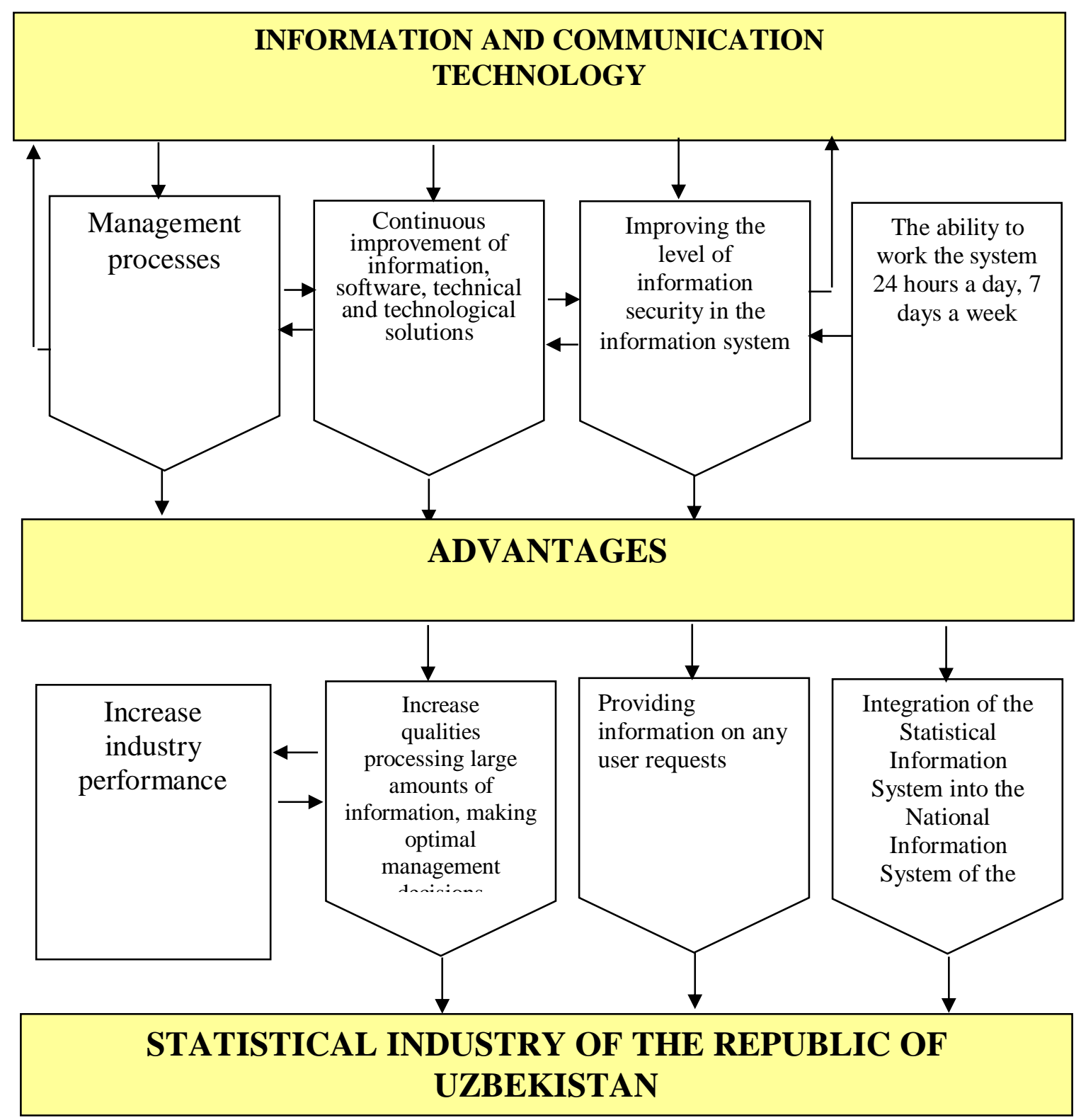

Fig. 6. The impact of information and communication technologies on the statistical industry of the Republic of Uzbekistan

As can be seen from fig. 6. ICTs contribute to the continuous improvement of information, software, technical and technological solutions, increase the level of information security, the ability to effectively use ICTs 24 hours a day, all 7 days a week [8], which in turn contributes to the effectiveness of management decisions at any level in statistical industry of the country. 


\section{CONCLUSION AND RECOMMENDATIONS}

Modern ICTs have enormous potential for stimulating social development. In particular, more and more modern ICTs are used in sectors and areas of the national economy and provide a huge range of public services.

Thus, we can say that the formation of a digital economy allows us to talk about the formation of a new management paradigm, based on the strengthening of the role of science as a leading productive force, generating more and more new knowledge and due to the following factors: tendencies towards differentiation of management, problems of information compatibility, process globalization and improving the social sphere of the national economy.

As recommendations for further improving the use of modern ICT methods and tools in managing the statistical industry, it is necessary to develop a methodology for integrating IP, as the need for processing more and more information is growing every day.

\section{REFERENCES}

1. Begalov B.A., Zhukovskaya I.E. Methodological foundations of the influence of information and communication technologies on the development of the national economy. Monograph. T .: IQTISODIYOT, 2018, 178 p.K.C., Laudon K. C., Laudon J. P. Management Information Systems. Managing the digital firm / 12th edition. New York: Prentice Hall, 2012. 677 p.

2. Couldry N., Powell A. Big data from the bottom up //Big Data \& Society. - 2014. - T. 1. - №. 2. - C. 277.

3. Frith J. Big data, technical communication, and the smart city //Journal of Business and Technical Communication. - 2017. - T. 31. - №. 2. - C. 168-187.

4. Maciejewski M. To do more, better, faster and more cheaply: Using big data in public administration //International Review of Administrative Sciences. - 2017. - T. 83. - №. 1_suppl. - C. 120-135.

5. Titorenko G.A. Information systems in the economy. - M.: Unity, 2008 .-- 258s.

6. Transformation of banks in the digital economy. // Collection of scientific works of students and graduate students edited by Kosarev V.E. M .: KnoRus, 2018 .- 277s.

7. Zhukovskaya I.E. The main aspects of the impact of information and communication technologies on the quality of management processes in the context of the digital economy. A collection of articles based on the results of the XIV international scientific and practical conference April 2526, 2019 "Modern management: problems and prospects". Publishing house of SPBGEU, 2019, p. $39-43$.

8. www.uz - official website of the National Information Search System of the Republic of Uzbekistan

9. www.stat.uz - the official website of the State Committee of the Republic of Uzbekistan on Statistics 